(C) И.А. Лизинфельд, Г.Ю. Журавлев, Н.Ю. Пшеничная, 2020

\title{
ОЦЕНКА ФАКТОРОВ, ВЛИЯЮЩИХ НА ЧАСТОТУ КОНТАКТОВ И ВТОРИЧНЫХ СЛУЧАЕВ COVID-19
}

\author{
И.А. Лизинфельд, Г.Ю. Журавлев, Н.Ю. Пшеничная
}

ФБУН «Центральный научно-исследовательский институт эпидемиологии» Роспотребнадзора, Москва, Россия

Резюме: Проведена оценка частоты контактов и вторичных случаев заболевания при различной локализации контактов с пациентами COVID-19. Оценка выполнена на основе отдельных данных мониторинга, проводимого Роспотребнадзором в январе-июне 2020. Полученные результаты демонстрируют высокий риск передачи инфекции в бытовых очагах во всех возрастных группах, что способствует распространению COVID-19 в популяции.

Цель исследования: анализ обстоятельств инфицирования при возникновении вторичных случаев COVID-19 для оптимизации мер по сдерживанию распространения инфекции.

Материалы и методы: Эпидемиологический анализ контактов с первичными случаями COVID-19 и вторичных случаев инфекции за 6 месяцев 2020 г., выполнен на основании отдельных данных мониторинга, проводимого Роспотребнадзором в зависимости от степени тяжести заболевания у первичных пациентов у 190856 больных COVID-19 и 146 996 контактных с ними лиц.

\section{Результаты:}

Наибольшее количество контактов было у больных легкой 50,6 \% и среднетяжелой 45,8 \% формами инфекции, что было обусловлено преобладанием среди заболевших именно этих форм COVID-19 (из всех анализируемых случаев COVID-19 50,0 \% составляли больные с легкой формой заболевания и 45,4\% больных со средне-тяжелой). Больные тяжелой формой встречались значительно реже 4,6\% случаев и, соответственно контактировали также реже. Удельный вес контактов с пациентами с тяжелой формой заболевания составил лишь 3,6\%.

В возрасте 41-64 лет отмечалось наибольшее количество заболевших 44,4\% и контактных - 44,5\%, в возрасте 18-40 лет - 30,2\% заболевших и 34,2\% контактных, 0-6 лет - 2,7\% и 717 лет - 4,0 \% заболевших и 1,9\% и 3,1\% контактных, соответственно. Количество контактных лиц напрямую было связано с числом возникновения вторичных случаев 
заболевания во всех возрастных группах: в возрасте 0-6 лет - 3,5 \%, 7-17 лет - 5,8 \%, 18-4033,9\%, 41-64 - 42,1\%, 65 и старше -14,7\% .

Пациенты всех возрастных групп преимущественно контактировали со здоровыми людьми в бытовых очагах: на возрастную группу 0-17 лет пришлось 65,9\% контактов, 18-40 лет - 63,9\%, 41-64 года- 64,2\% старше 65 лет -65,18\% соответственно.

Частота контактов по месту работы была максимальна в возрасте 18-40 лет - 9,0\% и 41-64 лет $-9,0 \%$, но, по большей части, значительно уступали показателям по контактам в быту - 63,8\% и 64,2\%, соответственно.

Основную роль в передаче инфекции в эпидемических очагах различной локализации играли больные в возрасте от 40 до 64 лет, составляя от 42,0\% в социальных учреждениях до 47,7\% в очагах по месту работы, за ними шла возрастая категория 18-40 лет, на которую приходилось от 30,6\% в очагах в медицинских организациях до 34,9\% в очагах по месту работы. 3-е место по удельному весу во всех эпидемических очагах составили пациенты в возрасте 65 лет и старше с максимумом в медицинских $(17,5 \%)$ и социальных (17,3\%) учреждениях. Дети и подростки 0-17 лет находились на последнем месте по удельному весу приходящихся на эту возрастную группу контактов. Удельный вес этой возрастной группы отмечен в различных образовательных учреждениях, общежитиях, интернатах и др. (10,0\%), а также в других организованных коллективах $(9,6 \%)$.

\section{Выводы:}

Наиболее активно передача инфекции осуществляется пациентами в возрасте 18-64 года, переносящими заболевание в легкой и средне-тяжелой форме. Вторичная передача наиболее активно происходит в бытовых очагах COVID-19у лиц всех возрастных групп. В возрастных группах 18-64 года немаловажное значение имеет также передача инфекции по месту работы. Полученные данные могут быть использованы для оптимизации мер по профилактике инфекции.

\section{Для корреспонденции:}

Лизинфельд Ирина Александровна, консультант организационно-методического отдела ФБУН «Центральный НИИ эпидемиологии» Роспотребнадзора

Адрес: 111123, Москва, ул. Новогиреевская, За

Телефон: +7 9999908080

E-mail: irinalizinfeld@gmail.com

ORCID: https://orcid.org/0000-0002-8114-1002

Статья получена г., принята к печати г. 